\title{
The Preventive Effects of Lactobacillus casei on Acute Lung Injury Induced by Lipopolysaccharide
}

\author{
Lihui Zhao ${ }^{1}\left(\right.$ Ying Mao $^{1} \cdot$ Haiming $\mathrm{Yu}^{1} \cdot \mathrm{He} \mathrm{Liu}^{1} \cdot$ Chao Wang $^{1} \cdot$

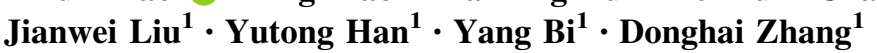

Received: 15 January 2021/Accepted: 24 May 2021/Published online: 1 June 2021

(C) Association of Microbiologists of India 2021

\begin{abstract}
Lactobacillus has been reported to inhibit acute lung injury (ALI). However, the molecular mechanism of Lactobacillus casei (L. casei) in preventing ALI has not been identified, so we investigated whether $L$. casei pretreatment could inhibit the activation of TLR4/MyD88/NF$\kappa \mathrm{B}$ signaling pathway following ALI. ALI model was established by intraperitoneal injection of $2 \mathrm{mg} / \mathrm{kg}$ lipopolysaccharide (LPS) to female BALB/c mice. In $L$. casei LC2W group, mice were intragastrically administrated L. case $i$ LC2W for a week, before the ALI modeling. The serum of normal BALB/c mice after intragastric administration of $\mathrm{L}$. casei LC2W was used for in vitro cell assays. The serum was pre-incubated with mouse macrophage cell line (RAW264.7) and human lung cell line (HLF-A), then LPS was added to co-incubate. Compared with ALI model group, L. casei LC2W pretreatment significantly reduced lung pathological damage, the number of neutrophils and total cells in bronchoalveolar lavage fluid. Besides, $L$. casei $\mathrm{LC} 2 \mathrm{~W}$ pretreatment could significantly reverse the abnormal expression of ICAM-1, IL-6, TNF- $\alpha$ and IL-10 in lung tissue and serum, plus, L. case $i$ LC2W significantly reduced the phosphorylation levels of IRAK-1 and NF- $\mathrm{KB}$ p65. In vitro, the serum decreased the up-regulation of IL- 6 and TNF- $\alpha$ in cell lines induced by LPS. In conclusion, L. casei LC2W intragastric administration pretreatment could significantly improve LPS-induced ALI in mice, probably through circulation to reach the lungs so
\end{abstract}

Lihui Zhao

zlh871218@163.com

1 the Second Affiliated Hospital of Qiqihar Medical University, No. 37 Zhonghua West Road, Jianhua DistrictHeilongjiang Province, Qiqihar City 161000, China as to inhibit the inflammatory response induced by acti-

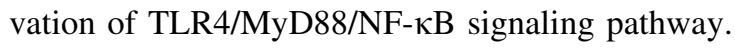

Keywords Lactobacillus · Acute lung injury $\cdot$ MyD88 dependent pathway $\cdot$ IRAK-1

\section{Introduction}

Acute lung injury (ALI) is the alveolar and pulmonary capillary injury caused by hemorrhagic shock, trauma, bacterial virus infection and other factors, resulting in diffuse pulmonary edema. The clinical manifestations are progressive hypoxemia and respiratory insufficiency along with uncontrolled inflammatory response. If ALI is not actively controlled, it is easy to develop into acute respiratory distress syndrome (ARDS), and the mortality rate can reach more than $40 \%$ [1]. The initiation and activation of a large number of inflammatory factors are involved in the occurrence and development of ALI, which leads to a series of inflammatory cascade reactions [2]. It can be seen that it is necessary to curb the uncontrolled inflammatory response in the lung induced by ALI in its prevention and treatment measures, and the immune system plays an extremely important role in the inflammatory response. However, there is still a lack of effective methods to inhibit inflammatory response, mainly via controlling the primary disease and respiratory support treatment to help recover.

In vivo and in vitro experiments have shown that intestinal flora can participate in mucosal immune response, thereby regulating innate immunity and $\mathrm{T}$ cell response [3]. Intestinal flora, including bacteria itself or metabolites, can also enter the blood circulation, then regulate the expression of cytokines, ultimately controlling lung inflammation $[4,5]$. This concept of regulating lung 
immune response by intestinal flora, that is, regulating the intestinal-pulmonary axis, has gradually been paid attention to in clinical and scientific research, but its specific mechanism has not been fully elucidated, and the study of Lactobacillus on the prevention of ALI has not been reported.

Lactobacillus is a common probiotics regulating the gastrointestinal tract, which stimulates the host to restore homeostasis by changing the intestinal micro-ecology. Studies have shown that Lactobacillus can stimulate the common mucosal immune system and protect other mucosal sites far from the intestine. For example, Lactobacillus reuteri down-regulated the expression of pro-inflammatory factors such as TNF- $\alpha$ and IL- 6 in blood and lung tissues of ALI mice, and inhibited apoptosis, posing immune-regulatory effects on ALI [6]. Lactobacillus rhamnosus reduced the number of inflammatory cells in the respiratory tract of asthmatic mice, and the level of IL- $1 \beta$ in lung tissue, along with restored the homeostasis of intestinal flora [7]. Lactobacillus plantarum inhibited the number of inflammatory cells in lung and bronchoalveolar lavage fluid of Klebsiella pneumoniae model mice, and down-regulated the expression of proinflammatory factors [8]. A double-blind placebo-controlled clinical study showed that Lactobacillus casei (L. casei) could reduce the incidence of pneumonia in patients with single rib fracture and improve lung function [9].

In our previous cell experiments, a $L$. casei strain LC2W was screened and found to have a good inhibitory effect on inflammation. On this basis, we intended to observe the effect of $L$. casei LC2W pretreatment on morphological damage and TLR4/MyD88/NF- $\mathrm{KB}$ signaling pathway in ALI model mice, as well as the inhibitory effect of mice serum after intragastric administration of $L$. casei LC2W on LPS-induced inflammatory response, in order to enrich the biological mechanism of Lactobacillus prevention and treatment of ALI, and provide new ideas for the development of new probiotics.

\section{Materials and Methods}

\section{Cultivation of Strain}

The standard strain of $L$. case $i \mathrm{LC} 2 \mathrm{~W}$ was extracted from Inner Mongolia local yogurt and stored in our laboratory. The purified $L$. casei $\mathrm{LC} 2 \mathrm{~W}$ strain was inoculated in a triangular flask containing $450 \mathrm{~mL}$ MRS liquid medium according to $1 \%$ inoculation amount. After $16 \mathrm{~h}$ of incubation in an anaerobic incubator at $37^{\circ} \mathrm{C}$, the bacteria were harvested by centrifugation at $4000 \mathrm{rpm}$ for $10 \mathrm{~min}$ at room temperature, and washed twice with 1640 medium (Solarbio, China, with phenol red), followed by re- suspension in 1640 medium containing $10 \%$ fetal bovine serum (Si ji qing, China). The optical density (OD) was measured at $620 \mathrm{~nm}$ to adjust the final concentration, and we determined the exact number of CFU by plating serial dilutions of the inoculum on MRS plates (Solarbio, Beijing, China).

\section{Mouse Feeding and Model Establishment}

The Animal Ethical Care Committee of Qiqihar Medical University has approved our protocol (ethical clearance number: QMU-AECC-2020-64). Forty SPF BALB/c female mice (8-week-old, 20-30 g/mouse, purchased from Charles River Laboratories, Beijing, China) were caged at $23 \pm 1{ }^{\circ} \mathrm{C}$ room temperature, for $12 \mathrm{~h} / 12 \mathrm{~h}$ in a light-dark cycle. Mice were fed with standard mouse food and pure water, without restriction of diet. After adapting to the environment for one week, the mice were randomly divided into four groups with 10 mice in each group, namely, the normal group, ALI model group (lipopolysaccharide, LPS), dexamethasone positive control group (DEX + LPS) and Lactobacillus experimental group (L. casei + LPS), in accordance with random number table. The same group was housed in the same cage, and each mouse was randomly selected when intragastrically administered. The L. casei + LPS group was given $0.1 \mathrm{~mL}$ of $L$. casei $\mathrm{LC} 2 \mathrm{~W}$ $\left(10^{9} \mathrm{CFU} / \mathrm{mL}\right.$ to ensure the final live bacteria dose at intestine reaching $\geq 10^{6} \mathrm{CFU} / \mathrm{mL}$ ) to each mouse daily for one week. The other groups were treated with equal volume of normal saline as control. The positive DEX + LPS control group was given dexamethasone $2 \mathrm{mg} / \mathrm{kg}$ by intraperitoneal injection $24 \mathrm{~h}$ before modeling. In reference to a previous report [10], for the LPS model group, the positive DEX + LPS control group and the L. case + LPS experimental group, LPS $(2 \mathrm{mg} / \mathrm{kg}$ of each mouce, Escherichia coli 055:B5, purchased from Sigma Corporation) was dissolved in $100 \mu \mathrm{L}$ of normal saline, thereafter injected intraperitoneally to construct ALI model, and the normal group was injected with the same volume $(100 \mu \mathrm{L})$ of normal saline. After $24 \mathrm{~h}$, mice were euthanized with anhydrous ether, then blood was collected via retro-orbital route and lungs were removed together. The following assays were performed in a blinded manner. Each sample was selected randomly in order to minimize the potential bias.

\section{Measuring Wet/Dry Weight of Lung Tissue by Electronic Scale}

The left lung was removed after thoracotomy, and the blood on the lung surface was cleaned by a paper. Then lung tissues were placed on the electronic scale for wet weight determination, thereafter lungs were incubated at 
$60{ }^{\circ} \mathrm{C}$ for $48 \mathrm{~h}$ to $72 \mathrm{~h}$ to remove all moisture. Subsequently, the dry weight was determined by electronic scale, and the wet/dry weight ratio was calculated.

\section{Morphological Evaluation of Lung Tissue}

We performed morphological evaluation according to the method reported by Ju et al.[11], in brief, after fixed with $4 \%$ paraformaldehyde for $24 \mathrm{~h}$, the lung tissues were embedded in paraffin for routine dehydration treatment, followed by preparation.

of $4 \mu \mathrm{m}$ slices. After dewaxing, the lung slices were stained with hematoxylin-eosin (HE) solution consecutively for $3 \mathrm{~min}$ and $10 \mathrm{~s}$ at ambient temperature. Pathological changes of lung tissues were observed under an optical microscope (magnification 200×, CKX41, Olympus), and imaging was assessed.

\section{Observation of Total Cells and Neutrophils in Bronchoalveolar Lavage Fluid (BALF)}

Mice lungs were washed three times with $0.5 \mathrm{~mL}$ of PBS, and the BALF was collected, as described previously [11]. The BALF cell pellet was re-suspended with $50 \mu \mathrm{l}$ of PBS, then centrifuged at $2500 \mathrm{rpm}$ for $15 \mathrm{~min}$ at $4{ }^{\circ} \mathrm{C}$. The supernatants were harvested and placed at $-80^{\circ} \mathrm{C}$ freezer. Wright Giemsa staining was used to count the number of neutrophils and total cells under the Olympus BX61WI microscope.

\section{Detection of Expression of Inflammatory Factors in Lung Tissue by Quantitative PCR (qPCR)}

The mRNA levels of IL-6, IL-10, TNF- $\alpha$ and NF- $\kappa$ B p65 in lung tissues were detected by qPCR as per Suzuki et al. [12]. Total RNA was extracted from lung tissue using TRIzol reagent, and the integrity of RNA was identified by $1 \%$ agarose gel electrophoresis. $1 \mu \mathrm{g}$ RNA was reverse transcribed into cDNA. The qPCR reaction system contained $10 \mu \mathrm{L} 2 \times$ SYBR Green Mixture, $1 \mu \mathrm{L}$ cDNA, $2 \mu \mathrm{L}$ primers $(10 \mu \mathrm{M})$ and $7 \mu \mathrm{L} \mathrm{ddH} 2 \mathrm{O}$. The primers used were listed below: IL-6 primer: forward 5'-CCAGAGATA CAMGAAATGATGG-3', reverse 5'-ACTCCAGMGACC AGAGGMAT-3'; IL-10 primer: forward 5'-GAGTGM GACCAGCAAAGGC-3', reverse 5'-TTGTCCAGCTGG TCCTT-3'; TNF- $\alpha$ primer: forward 5'-CGGCTA CCTAGTCTACGCC-3', reverse $5^{\prime}$-AAGTCGCCGCCAATGTTGA- $3^{\prime}$; NF- $\kappa$ B p 65 primer: forward $5^{\prime}$-ATCCC ATCTTTGACAATCGTGC- $3^{\prime}$, reverse $5^{\prime}$-CTGGTCCCG TGAAATACACCTC- $3^{\prime}$. Reaction conditions were as follows: $95{ }^{\circ} \mathrm{C}$ for $10 \mathrm{~min}, 40$ cycles of $95{ }^{\circ} \mathrm{C}$ for $15 \mathrm{~s}$, and then $60{ }^{\circ} \mathrm{C}$ for $60 \mathrm{~s}$. RT-PCR reaction was processed in ViiA TM 7 Real-time PCR system (Thermo Fisher
Scientific, Waltham, USA). Each sample was subjected to three parallel tests. We selected $\beta$-actin as the internal reference.

\section{Expression of ICAM-1, IL-6, IL-10 and TNF- $\alpha$ in Lung and Serum by Enzyme Linked Immune Sorbent Assay (ELISA)}

About $5 \mathrm{mg}$ of mouse lung tissue was put into the tube, and about $300 \mu \mathrm{L}$ of complete extraction buffer was added. The homogenate was homogenized on ice by an electric homogenizer, and centrifuged at 13,000 rpm for $20 \mathrm{~min}$. The supernatants were collected in pre-cooling fresh and marked tubes, then preserved at $-80{ }^{\circ} \mathrm{C}$. The serum obtained from mice was centrifuged at $4000 \mathrm{rpm}$ for 10 min at $4{ }^{\circ} \mathrm{C}$, and supernatant was collected. In accordance with Liang et al. [13], the expressions of ICAM-1, IL-6, IL-10 and TNF- $\alpha$ protein in both lungs and serum were detected according to the instructions of ELISA kit (purchased from Nanjing Jiancheng Bioengineering Institute, China). The corresponding OD values were measured by a microplate reader at $450 \mathrm{~nm}$ wavelength, and a standard curve was obtained. According to the sample OD values, ICAM-1, IL-6, IL-10 and TNF- $\alpha$ protein levels were calculated with reference to the standard curve.

\section{Expression of IRAK, p-IRAK, NF-kB p65 and p-NF- kB p65 in Mouse Lung Tissue by Western Blotting}

The protocol of western blotting was performed according to Zhang $\mathbf{J}$ et al. [14]. Briefly, lung tissues were collected and ground into powder in liquid nitrogen instantly. Then we dissolved the powder in protein loading buffer at a ratio of 1:10 (tissue/buffer) and boiled it for $5 \mathrm{~min}$. After cooling to ambient temperature, the supernatant was collected for spare. A BCA protein assay kit (Thermo Fisher Scientific, Inc.) was used for protein quantification measurement. Thereafter, $25 \mu \mathrm{g}$ proteins (each sample) were separated on $10 \%$ SDS-PAGE gels, then electroblotted onto PVDF membranes (Millipore, Billerica, MA, USA). The blots were blocked in $5 \%$ skim milk for $1 \mathrm{~h}$ at $37{ }^{\circ} \mathrm{C}$, and then incubated with various primary antibodies including antiIRAK polyclonal antibody (rabbit, 1:1000, solarbio, China), anti-p-IRAK polyclonal antibody (rabbit, 1:1000, solarbio, China), anti-NF-kB p65 polyclonal antibody (rabbit, 1:1000, solarbio, China), anti-p-NF-kB p65 polyclonal antibody (rabbit, 1:1000, solarbio, China), and anti$\beta$-actin polyclonal antibody (rabbit, 1:2000, solarbio, China) overnight at $4{ }^{\circ} \mathrm{C}$, followed by incubation with goat anti-rabbit $\mathrm{IgG} /$ horseradish peroxidase antibody (rabbit, 1:5000, Solarbio, China) at ambient temperature for $1 \mathrm{~h}$. The bands were quantified using Carestream molecular imaging software. 


\section{In Vitro Assays}

\section{Serum Preparation}

Each mouse was given gavage administration of $0.1 \mathrm{~mL} L$. casei LC2W suspension $\left(10^{9} \mathrm{CFU} / \mathrm{mL}\right)$ for one week. Subsequently, blood was collected from eyeball for each mouse under sterile conditions. After overnight storage in a refrigerator at $4{ }^{\circ} \mathrm{C}$, the serum was completely separated, then samples were centrifuged at $4000 \mathrm{rpm}$ for $10 \mathrm{~min}$ at $4{ }^{\circ} \mathrm{C}$, ending up with the upper layer serum supernatant transferred in another sterile centrifuge tube and stored at 4 ${ }^{\circ} \mathrm{C}$ for subsequent assays.

\section{Mouse Macrophage Cell Line (RAW264.7) Culture Experiment}

The cell culture was carried out in accordance to a reference [15]. The DMEM medium with $10 \%$ fetal bovine serum was used as the main medium, and $1 \%$ penicillinstreptomycin double antibody was added. The mouse macrophages were cultured in a 5\% CO2 incubator at $37{ }^{\circ} \mathrm{C}$, and the cell density was required to reach $85 \%$ to $90 \%$ for passage. Isolated cells were divided into three groups: blank group (control), model group (LPS) and serum group (L. casei + LPS). The blank group was only added with the same volume of normal saline. The model group was stimulated with $80 \mathrm{ng} / \mathrm{mL}$ LPS. The serum group was preincubated with $2 \%$ mouse serum for $2 \mathrm{~h}$, and then stimulated with $80 \mathrm{ng} / \mathrm{mL}$ LPS. After LPS stimulation for $6 \mathrm{~h}$, the total RNA of each group was extracted, and the transcription levels of IL- 6 and TNF- $\alpha$ were examined by qPCR. In addition, the cell supernatant was collected for ELISA to detect the expression changes of IL-6 and TNFa. Each experiment was repeated three times independently.

\section{In Vitro Experiment of Human Lung Cell Lines (HLF-A)}

HLF-A cells were divided into three groups: blank group (control), model group (LPS) and serum group ( $L$. case $i+$ LPS). The treatment in each group was performed the same as in the RAW264.7 cells. Likewise, the transcription levels and protein expressions of IL-6 and TNF- $\alpha$ in the cell supernatants were determined by qPCR and ELISA assays.

\section{Statistical Analysis}

All experiments were carried out at least three times. SPSS13.0 statistical software was used for data analysis, and Graphpad Prism5 (San Diego, CA) was used to draw the graph. Kolmogorov-Smirnov test was firstly done to detect whether data fit normal distribution, if fit, one-way ANOVA was used to compare the differences between the four groups, and LSD-t test was performed when the difference was significant. Otherwise, Kruskal-Wallis $\mathrm{H}$ and Mann-Whitney $\mathrm{U}$ test were applied alternatively. $P<0.05$ indicated statistical difference, $P<0.01$ representing significant statistical difference, and $P<0.001$ for extremely significant statistical difference.

\section{Results}

\section{Effect of Lactobacillus on ALI}

\section{Wet/dry Weight Ratio of Lung Tissue}

Compared with the normal group $(4.22 \pm 0.49)$, the wet/ dry weight ratio of lung tissues in the ALI model group $(6.30 \pm 0.45)$ was significantly increased $(P<0.001$, Fig. 1). Compared with the ALI model group, the wet/dry weight ratios of lung tissues in both the L.casei + LPS experimental group $(5.17 \pm 0.25)$ and the positive

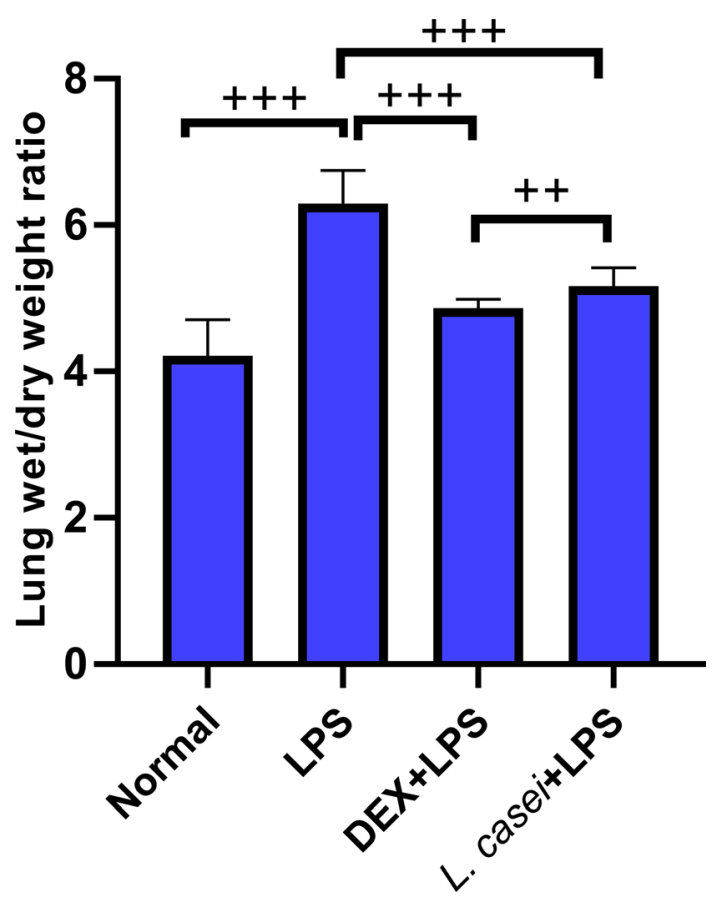

Fig.1 Effect of Lactobacillus casei LC2W on wet/dry weight ratio of lung tissue in mice with acute lung injury (ALI) Normal represents mice group treated with normal saline, LPS refers to ALI mouse models by intraperitoneal injection of LPS, DEX + LPS was a positive control group by intraperitoneal injection of dexamethasone before ALI model was established, and L.casei + LPS was an experimental group intervened by Lactobacillus casei LC2W pretreatment prior to ALI modeling. The values were expressed as mean $\pm \mathrm{SD}$, with 10 mice in each group. $++P<$ $0.05 ;+++P<0.001$ 
DEX + LPS control group $(4.87 \pm 0.12)$ were significantly decreased $(P<0.001$, Fig. 1$)$. The reduction in DEX + LPS control group was significantly larger when compared with that in L.casei + LPS experimental group $(P<0.01$, Fig. 1).

\section{HE Staining}

HE staining results are shown in Fig. 2. Normal mice alveolar was complete, and alveolar wall was thin, with uniform shape. Pulmonary interstitial was not swelling, and bronchial was tight with no exudation. In the ALI model group, alveolar fusion and collapse formed pulmonary bullae, and alveolar septum tissue was thickened, as well as with a large number of inflammatory cells infiltrated in the bronchus. Compared with the model group, the alveolar structure in the L.casei + LPS experimental group was slightly damaged, with less inflammatory cell infiltration, no obvious bleeding and exudation in the bronchus. Plus, the alveolar interior was clean and transparent, with reduced alveolar interstitial swelling. Likewise, in the positive DEX + LPS control group when compared with the model group, the alveolar structure damage was relatively milder, and the alveolar wall was more complete,

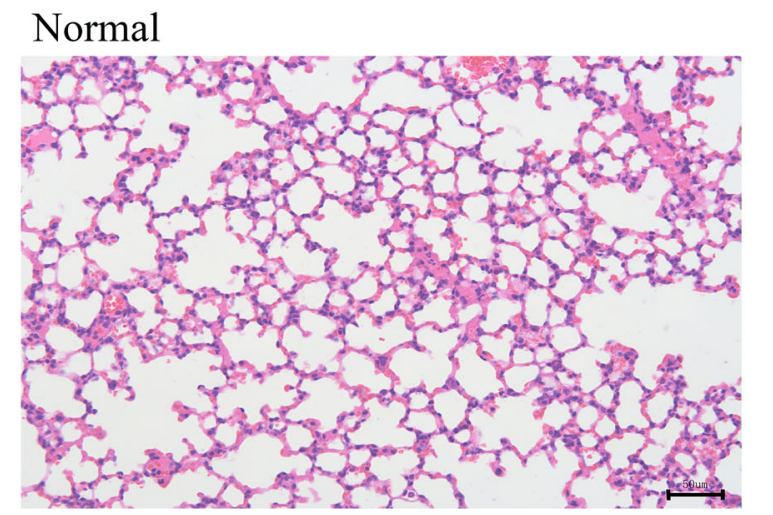

\section{DEX+LPS}

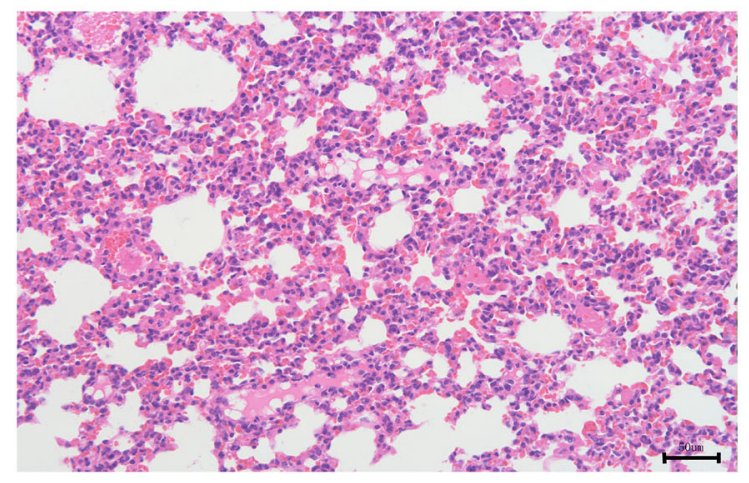

Fig.2 Histopathological sections of hematoxylin-eosin (HE) stained lung tissue (magnification $\times 200$, scale bar $=50 \mu \mathrm{m}$ ) Normal represents mice group treated with normal saline, LPS refers to ALI mouse models by intraperitoneal injection of LPS, DEX + LPS was a accompanied by clearer alveolar cavity contour, and less inflammatory damage.

\section{BALF Cell Counts}

BALF was collected and stained with Wright Giemsa. The number of neutrophils and total cells was counted under microscope, and the results are shown in Fig. 3. Compared with the normal group, the number of neutrophils and total cells in BALF of the ALI model group were increased significantly (both with $P<0.001$ ). After pre-treated by DEX and $L$. casei $\mathrm{LC} 2 \mathrm{~W}$, the number of neutrophils and total cells in BALF were both significantly reduced in comparison to ALI model group (both with $P<0.001$ ).

\section{Effect of Lactobacillus Intervention on Transcription of Inflammatory Factors in Lung Tissue}

The transcription changes of inflammatory factors IL-6, IL10 , TNF- $\alpha$ and NF- $\mathrm{KB}$ p65 in lung tissues detected by qPCR are shown in Fig. 4. The change trends of IL-6 and TNF- $\alpha$ were basically the same. The relative content of IL6 mRNA in the normal group was $0.52 \pm 0.02$, and that in the model group was significantly increased, which was
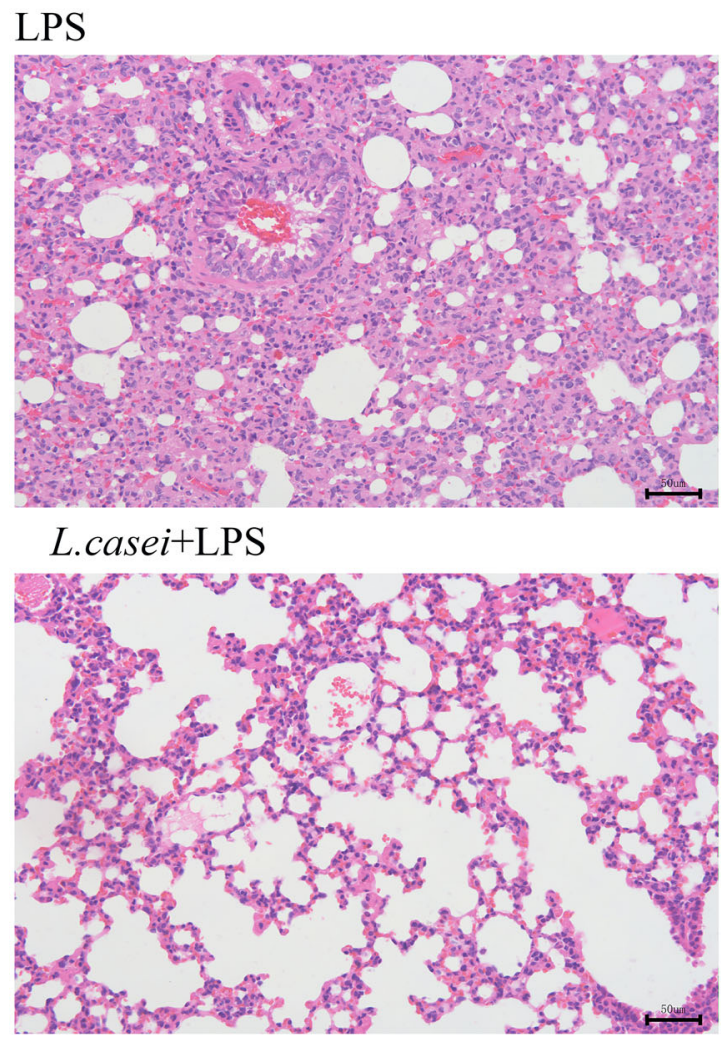

positive control group by intraperitoneal injection of dexamethasone before ALI model was established, and L.casei + LPS was an experimental group intervened by Lactobacillus casei LC2W pretreatment prior to ALI modeling 


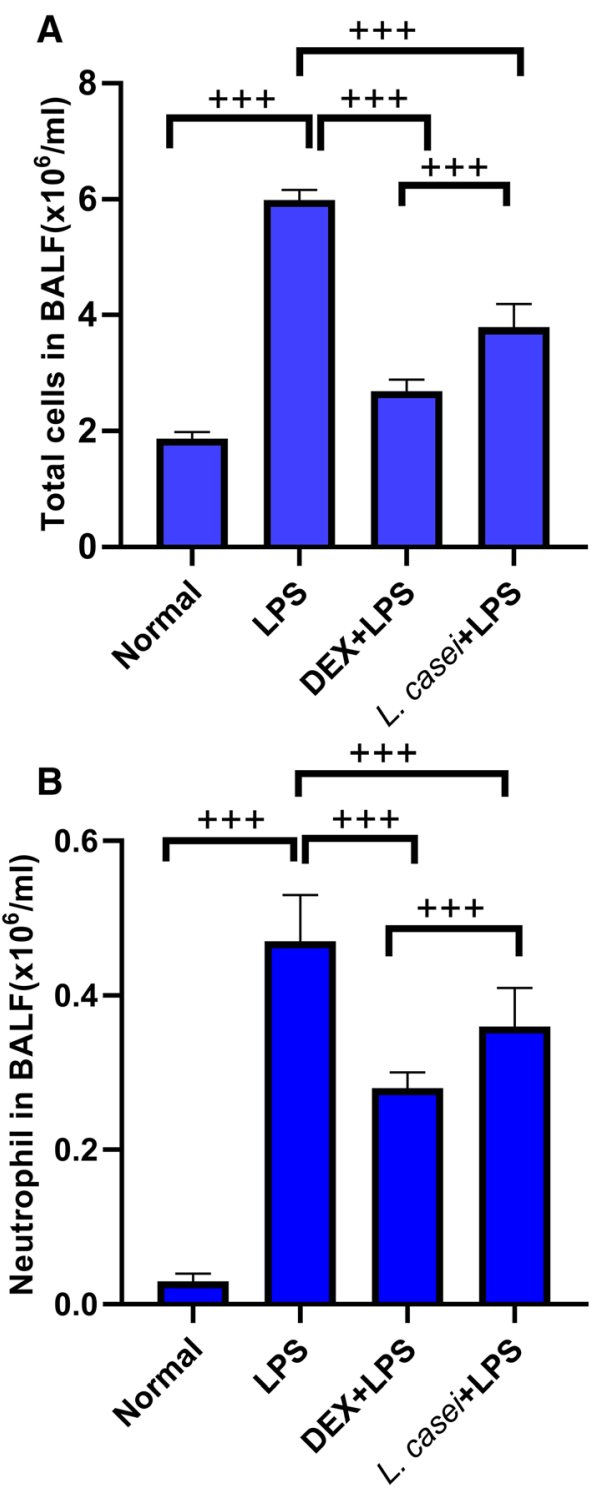

Fig.3 Effect of Lactobacillus casei LC2W on white blood cell count in BALF of mice with acute lung injury A. Total cell count in BALF; B. The number of neutrophils in BALF. Normal represents mice group treated with normal saline, LPS refers to ALI mouse models by intraperitoneal injection of LPS, DEX + LPS was a positive control group by intraperitoneal injection of dexamethasone before ALI model was established, and L.casei + LPS was an experimental group intervened by Lactobacillus casei LC2W pretreatment prior to ALI modeling. The values were expressed as mean $\pm \mathrm{SD}$, with 10 mice in each group. $+++P<0.001$

$3.31 \pm 0.12$, with a statistical difference between groups $(P<0.001)$. After intragastric administration of $L$. case $i$ LC2W, IL-6 mRNA in ALI mice was decreased significantly to $2.82 \pm 0.22$, relative to ALI model group $(P<0.001)$, and the reduction was much more regarding IL-6 mRNA in dexamethasone positive control group when compared both with ALI model group and L. casei + LPS group $(P<0.001, P<0.01)$. IL-10 mRNA levels in the lung tissue of the model group and normal group were $2.72 \pm 0.48$ and $0.75 \pm 0.06$, respectively, which differed remarkably $(P<0.001)$. Compared with the ALI model group, IL-10 mRNA levels in the $L$. casei LC2W group were significantly increased $(3.60 \pm 0.44, P<0.001)$, and the increase was significantly greater than that in the dexamethasone positive control group $(P<0.01)$. While IL-10 mRNA levels in the positive control group were not significantly different from those in the model group $(P>0.05)$. The expression level of NF- $\mathrm{kB}$ p65 mRNA in L. casei $\mathrm{LC} 2 \mathrm{~W}$ group $(1.80 \pm 0.29)$ was lowered significantly when compared with the ALI model group $(2.35 \pm 0.10, P<0.001)$. The trend of NF- $\kappa \mathrm{B}$ p65 mRNA expression in Dex + LPS group was similar to that in $L$. casei LC2W group.

Changes in Expression Levels of Cytokines in Lung Tissue and Blood of Mice after Lactobacillus Intervention

The lung tissues and serum samples of mice in each group were taken, and the expression levels of ICAM-1, IL-6, IL10 and TNF- $\alpha$ were detected by ELISA. The results are shown in Fig. 5. In the lung tissues of ALI model group, the expression of ICAM-1 protein that promotes chemotaxis and migration of inflammatory cells was $250.46 \pm 21.65 \mathrm{pg} / \mathrm{mL}$, which was significantly higher than that in the normal group $(20.47 \pm 1.65 \mathrm{pg} / \mathrm{mL}$, $P<0.001$ ), after intragastric administration of $L$. casei LC2W, ICAM-1 expression was decreased to $170.24 \pm 21.16 \mathrm{pg} / \mathrm{mL}$, and the difference between the two groups was significant $(P<0.001)$. There was no significant difference between the dexamethasone positive control group and the $L$. casei group $(P>0.05)$. IL-6 and TNF- $\alpha$ expressions showed similar phenomena. In the lung tissues of the model group, the IL-10 protein content was $89.79 \pm 8.77 \mathrm{pg} / \mathrm{mL}$, which was significantly higher than that in the normal group $(P<0.001)$. L. casei LC2W pretreatment significantly up-regulated IL-10 protein content to $125.93 \pm 4.78 \mathrm{pg} / \mathrm{mL}$, when compared to that in the model group $(P<0.001)$. The IL-10 expression level of $L$. casei LC2W group was the highest in all groups, statistically different compared with the DEX positive control group $(P<0.01)$.

The serum ICAM-1 protein level in ALI model group was significantly higher than that in normal group $(18.62 \pm 2.10 \mathrm{pg} / \mathrm{mL}$ vs. $2 \pm 0.33 \mathrm{pg} / \mathrm{mL}, P<0.001)$. After intragastric administration of $L$. casei $\mathrm{LC} 2 \mathrm{~W}$, the expression of ICAM-1 protein was decreased to $14.08 \pm 0.16 \mathrm{pg} / \mathrm{mL}$. The comparison between the two groups was statistically significant $(P<0.001)$. The changes of pro-inflammatory cytokines IL- 6 and TNF- $\alpha$ were similar to those of ICAM-1. The expression of serum IL-10 protein in ALI model group was $178.95 \pm 11.34 \mathrm{pg}$ / 

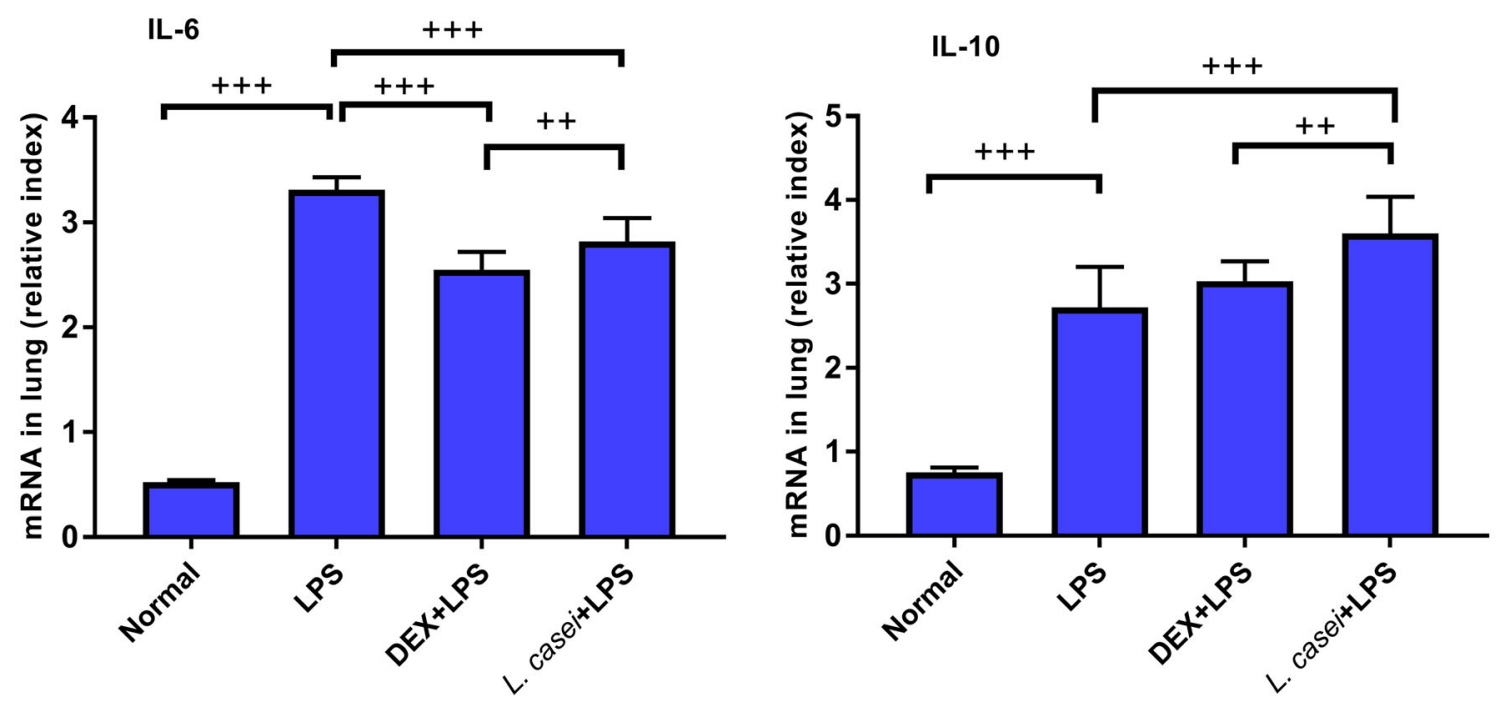

TNF- $\alpha$

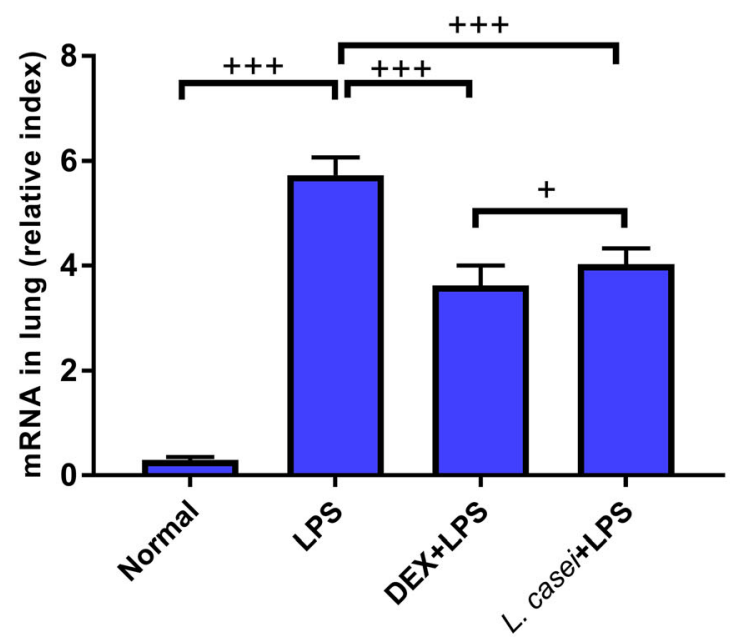

Fig.4 The effect of $L$. case $i \mathrm{LC} 2 \mathrm{~W}$ pretreatment on the transcription of inflammatory cytokines in lung tissue of ALI mice Normal represents mice group treated with normal saline, LPS refers to ALI mouse models by intraperitoneal injection of LPS, DEX + LPS was a positive control group by intraperitoneal injection of dexamethasone

$\mathrm{mL}$, which was significantly higher than that in normal group $(8.77 \pm 0.20 \mathrm{pg} / \mathrm{mL}, P<0.001)$. After $L$. casei LC2W pretreatment, serum IL-10 protein level was elevated to $242.63 \pm 6.84 \mathrm{pg} / \mathrm{mL}$, which was significantly different from that in model group $(P<0.001)$ and DEX positive control group $(226.63 \pm 19.9 \mathrm{pg} / \mathrm{mL}, P<0.05)$. Both blood and lung tissues showed the same changes, indicating that $L$. casei $\mathrm{LC} 2 \mathrm{~W}$ intervention can reduce ALI-induced inflammatory response, thereby reducing the damage caused by ALI.

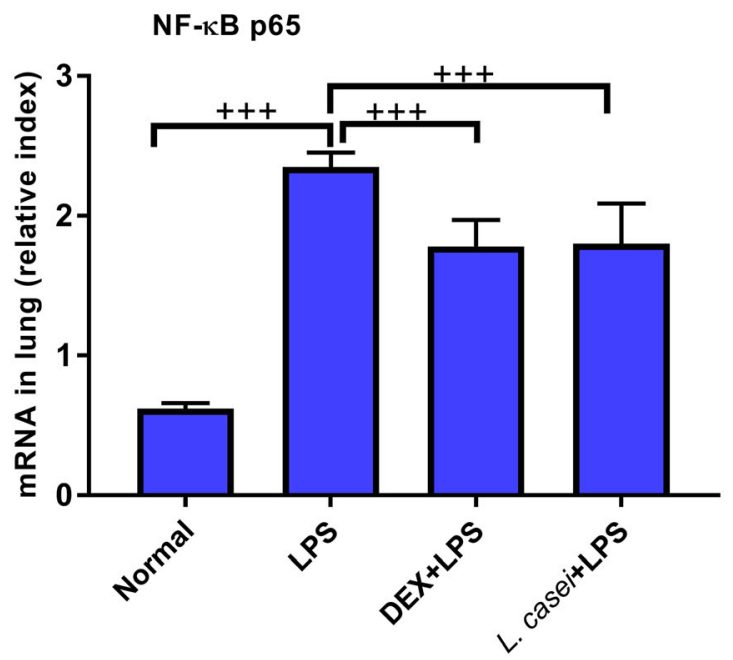

before ALI model was established, and L.casei + LPS was an experimental group intervened by Lactobacillus casei LC2W pretreatment prior to ALI modeling. The values were expressed as mean $\pm \mathrm{SD}$, with 10 mice in each group. $+P<0.05 ;++P<0.01 ;+++P<0.001$

Effect of Lactobacillus on TLR4-induced My D88dependent Pathway Key Protein Expression and Phosphorylation

After separation and extraction of total protein of lung cells, protein gel electrophoresis, phosphorylation results are shown in Fig. 6. There was no change in the expression of IRAK-1 protein among all groups, but the phosphorylation level of IRAK-1 in the model group was significantly increased $(P<0.001)$. The relative expression level of p-IRAK-1/IRAK-1 was $0.85 \pm 0.07$, indicating that LPS induced the activation of MyD88 dependent pathway transduced by TLR-4, leading to IRAK-1 autophosphorylation. After L. casei $\mathrm{LC} 2 \mathrm{~W}$ intervention, the 

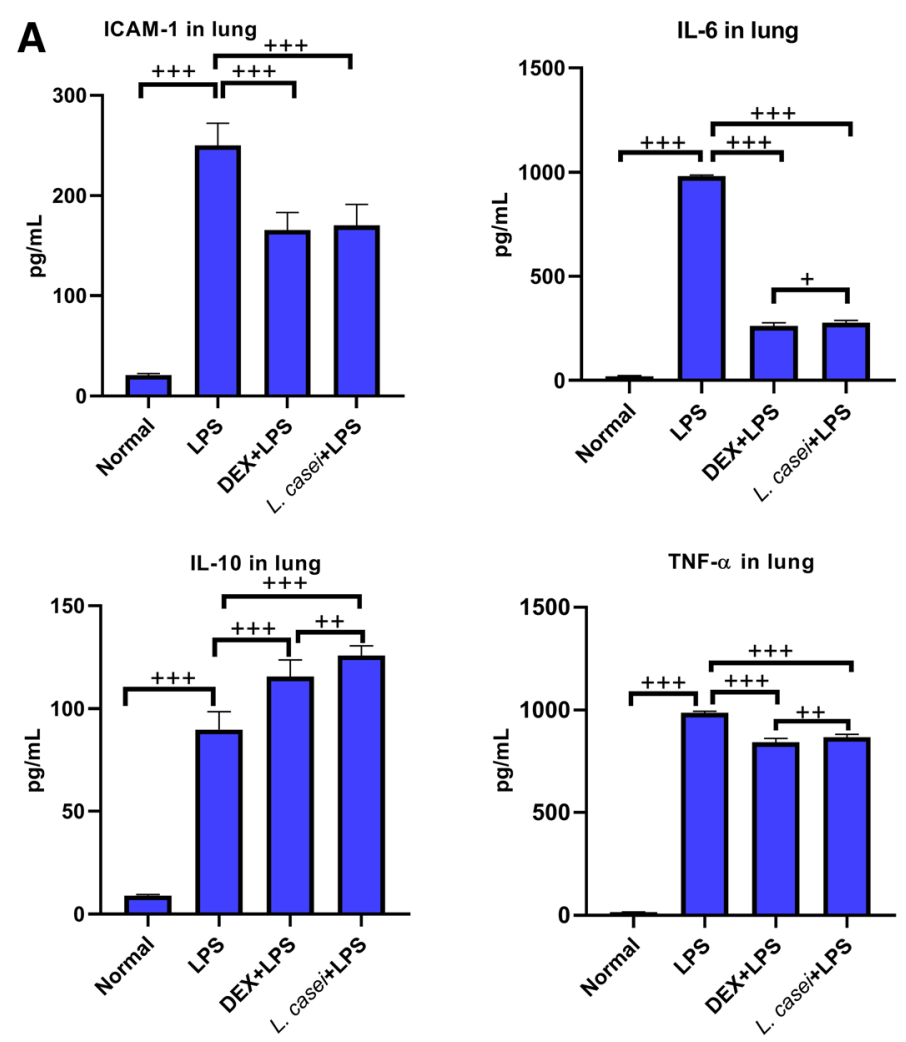

B
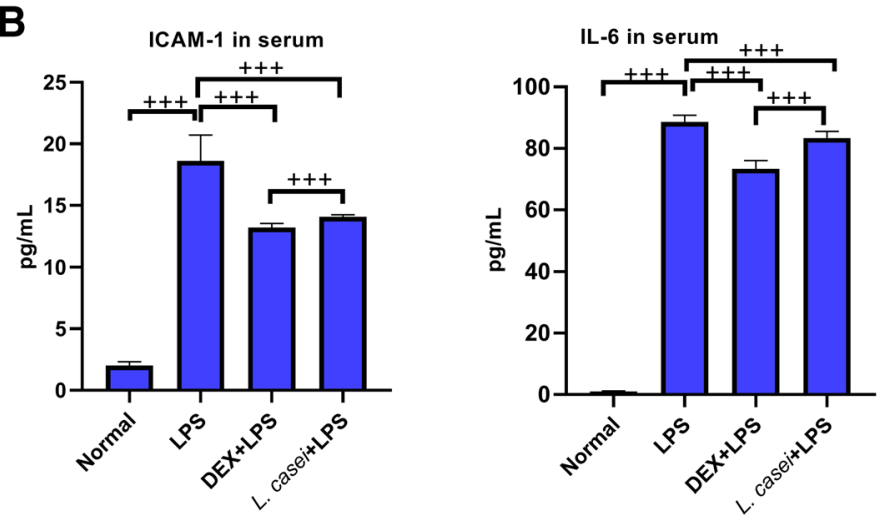

IL-10 in serum
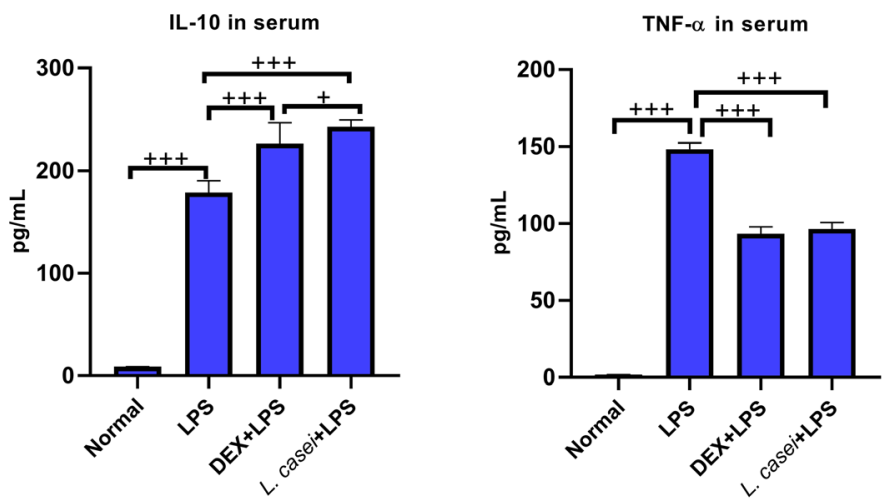
4Fig.5 Effect of Lactobacillus casei LC2W on the expression of inflammatory cytokines in lung tissue and serum of ALI mice A. The expression of ICAM-1, IL-6, IL-10 and TNF- $\alpha$ in lung tissue was measured by ELISA. B. ELISA was used to measure the expression of ICAM-1, IL-6, IL-10 and TNF- $\alpha$ in serum. Normal represents mice group treated with normal saline, LPS refers to ALI mouse models by intraperitoneal injection of LPS, DEX + LPS was a positive control group by intraperitoneal injection of dexamethasone before ALI model was established, and L.casei + LPS was an experimental group intervened by Lactobacillus casei $\mathrm{LC} 2 \mathrm{~W}$ pretreatment prior to ALI modeling. The values were expressed as mean $\pm \mathrm{SD}$, with 10 mice in each group. $+P<0.05,++P<0.01,+++P<0.001$

phosphorylation level of IRAK-1 was significantly decreased, and the relative expression of p-IRAK-1/ IRAK1 in L. casei LC2W group was $0.71 \pm 0.05$. Compared with the model group, the difference was statistically significant $(P<0.001)$. The relative expression of p-NF- $\kappa \mathrm{B}-$ p65/NF- $\kappa B-p 65$ in model group was $0.80 \pm 0.08$, and that in $L$. case $i \mathrm{LC} 2 \mathrm{~W}$ group was $0.62 \pm 0.05$. The NF- $\mathrm{\kappa B}-\mathrm{p} 65$ phosphorylation levels in $L$. casei $\mathrm{LC} 2 \mathrm{~W}$ group were significantly lower than those in model group $(P<0.001)$.
Decreased Inflammation in Vitro Cell Lines after Treatment by Serum of L. casei LC2W Administered Mice

The serum of normal mice after intragastric administration of L. casei $\mathrm{LC} 2 \mathrm{~W}$ was used for in vitro experiments. We found that the serum of mice after intervention of $L$. casei $\mathrm{LC} 2 \mathrm{~W}$ could reverse the LPS-stimulated inflammatory effect both on mouse macrophage cell line (RAW264.7), and human lung cell line (HLF-A), as shown in Figs. 7 and 8.

LPS could induce the significant increase in the transcriptional level and protein expression of IL- 6 and TNF- $\alpha$ in RAW264.7 cell lines, with the protein contents of $778.29 \pm 13.36 \mathrm{pg} / \mathrm{mL}$ and $970.25 \pm 16.65 \mathrm{pg} / \mathrm{mL}$, respectively (all $P<0.001$ ). After pre-incubation with mouse serum after intragastric administration of $L$. casei LC2W, the transcription level and protein expression of these two pro-inflammatory cytokines were significantly inhibited, among which the protein expression decreased to $734.80 \pm 19.80 \mathrm{pg} / \mathrm{mL}$ and $885.51 \pm 14.84 \mathrm{pg} / \mathrm{mL}$, respectively, both were significantly different from LPS group $(P<0.05$ for IL-6, $P<0.01$ for TNF- $\alpha)$. In addition, LPS could also induce the increase in the transcription level and protein expression of IL- 6 and TNF- $\alpha$ in HLF-A
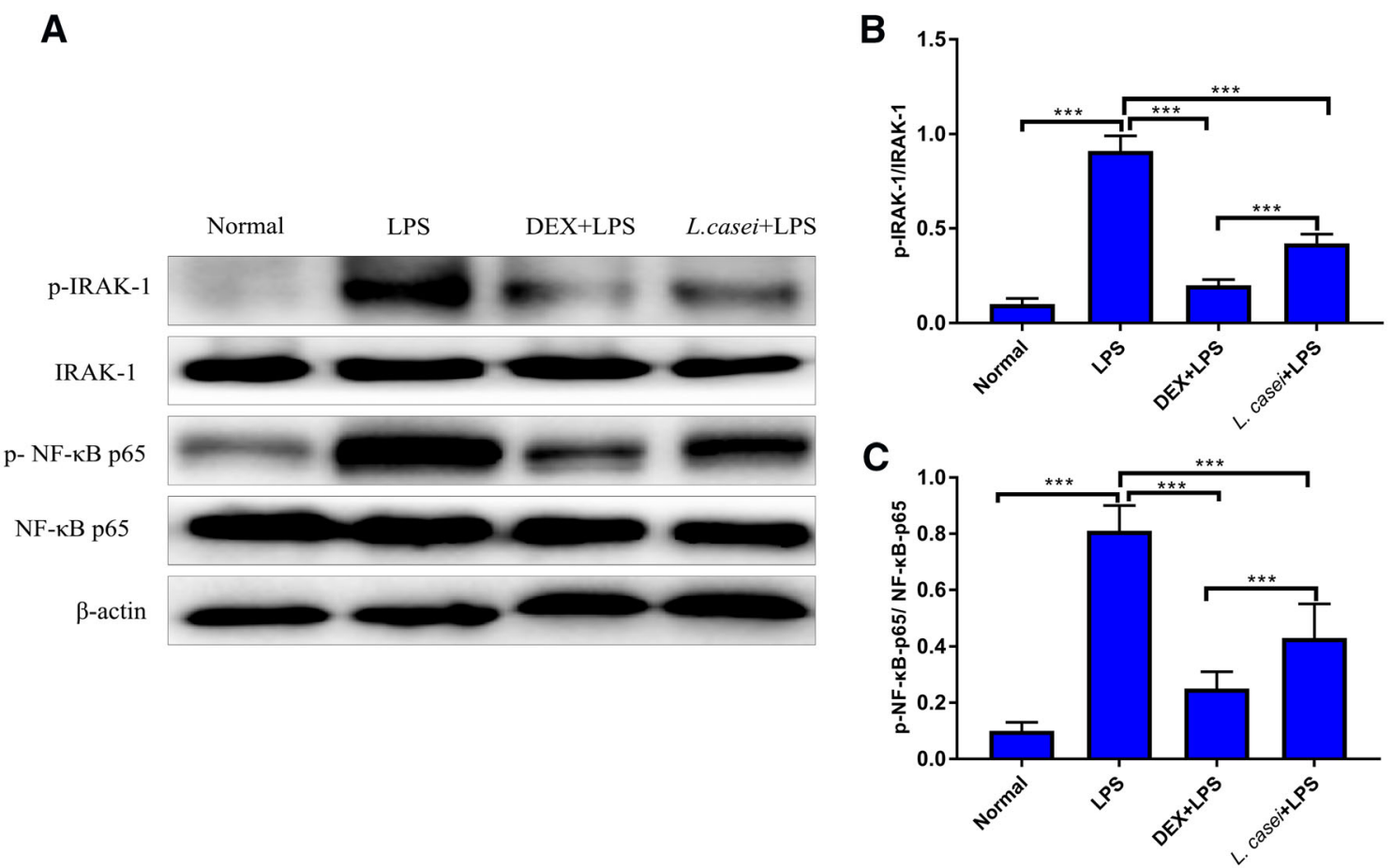

Fig.6 Effect of Lactobacillus casei LC2W pretreatment on the expression and phosphorylation of IRAK-1 and p65 protein in lung tissue. A. Western blotting of IRAK-1 and p65 protein and relative phosphorylation. B. Relative expression of p-IRAK-1/IRAK-1. C. Relative expression of p-NF- $\mathrm{B}-\mathrm{p} 65 / \mathrm{NF}-\kappa \mathrm{B}-\mathrm{p} 65$, quantified from western blotting. Normal represents mice group treated with normal saline, LPS refers to ALI mouse models by intraperitoneal injection of LPS, DEX + LPS was a positive control group by intraperitoneal injection of dexamethasone before ALI model was established, and L.casei + LPS was an experimental group intervened by Lactobacillus casei $\mathrm{LC} 2 \mathrm{~W}$ pretreatment prior to ALI modeling. The values were expressed as mean $\pm \mathrm{SD}$, with 10 mice in each group. $++P<0.01,+++P<0.001$ 

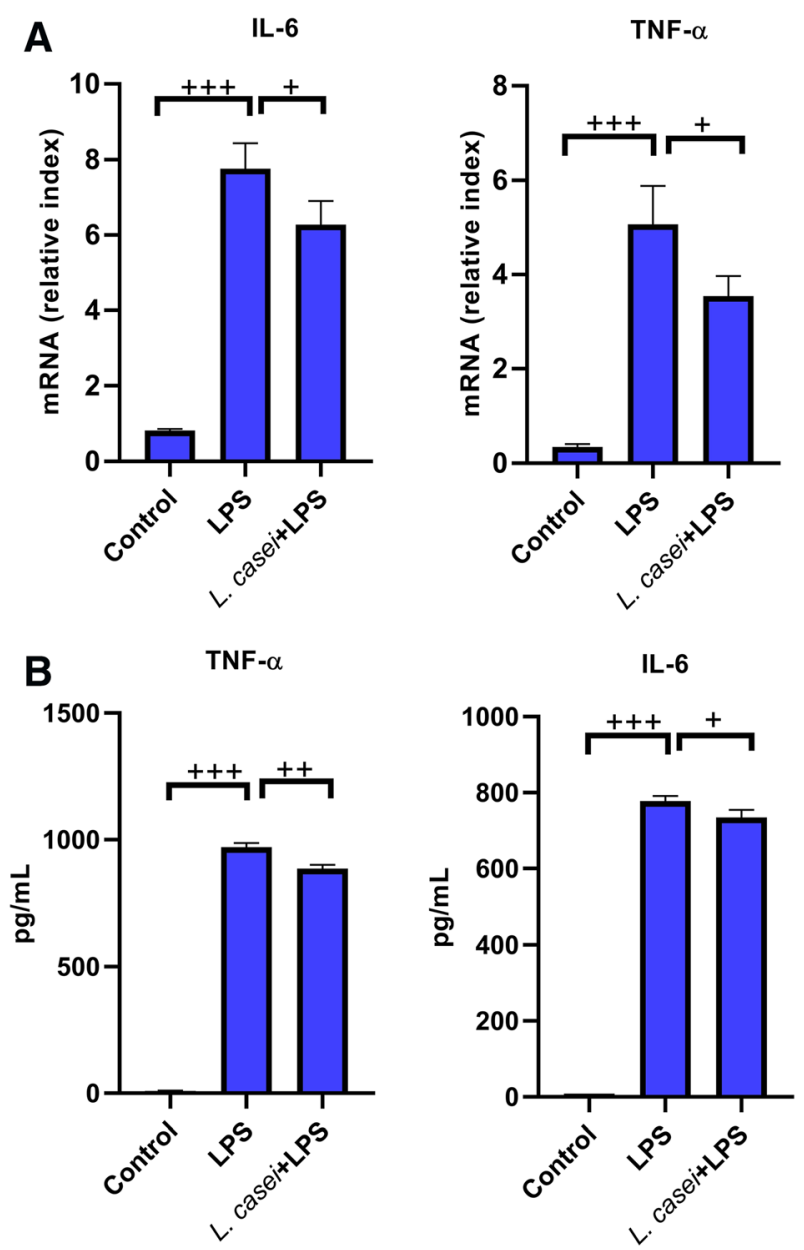

Fig.7 The effects of mouse serum after intragastric administration of Lactobacillus on the mRNA and protein expression of IL-6 and TNF$\alpha$ in mouse macrophage cell line (RAW264.7). The transcription level was detected by qPCR (a). The protein level was detected by ELISA (b). Control is a blank group only incubated with equal volume of normal saline. LPS is stimulated with $80 \mathrm{ng} / \mathrm{mL}$ LPS. L.casei + LPS is pre-incubated with $2 \%$ mouse serum for $2 \mathrm{~h}$, and then stimulated with $80 \mathrm{ng} / \mathrm{mL}$ LPS. The values were expressed as mean $\pm \mathrm{SD}$, and experiments were repeated 3 times. $+P<0.05,++P<$ $0.01,+++P<0.001$

cell lines, with the protein contents of $988.98 \pm 17.05 \mathrm{pg}$ / $\mathrm{mL}$ and $772.47 \pm 10.09 \mathrm{pg} / \mathrm{mL}$, respectively $(P<0.001)$. Pretreatment by mouse serum significantly decreased both the transcriptional levels and protein expressions of IL-6 and TNF- $\alpha$, with latter values of $883.91 \pm 15.13 \mathrm{pg} / \mathrm{mL}$ and $670.71 \pm 18.85 \mathrm{pg} / \mathrm{mL}$ (both $P<0.01$ relative to LPS group).

\section{Discussion}

ALI is caused by various direct or indirect factors with the characteristics of diffuse interstitial lung and alveolar edema, about $30 \%$ to $50 \%$ of the cases are caused by severe
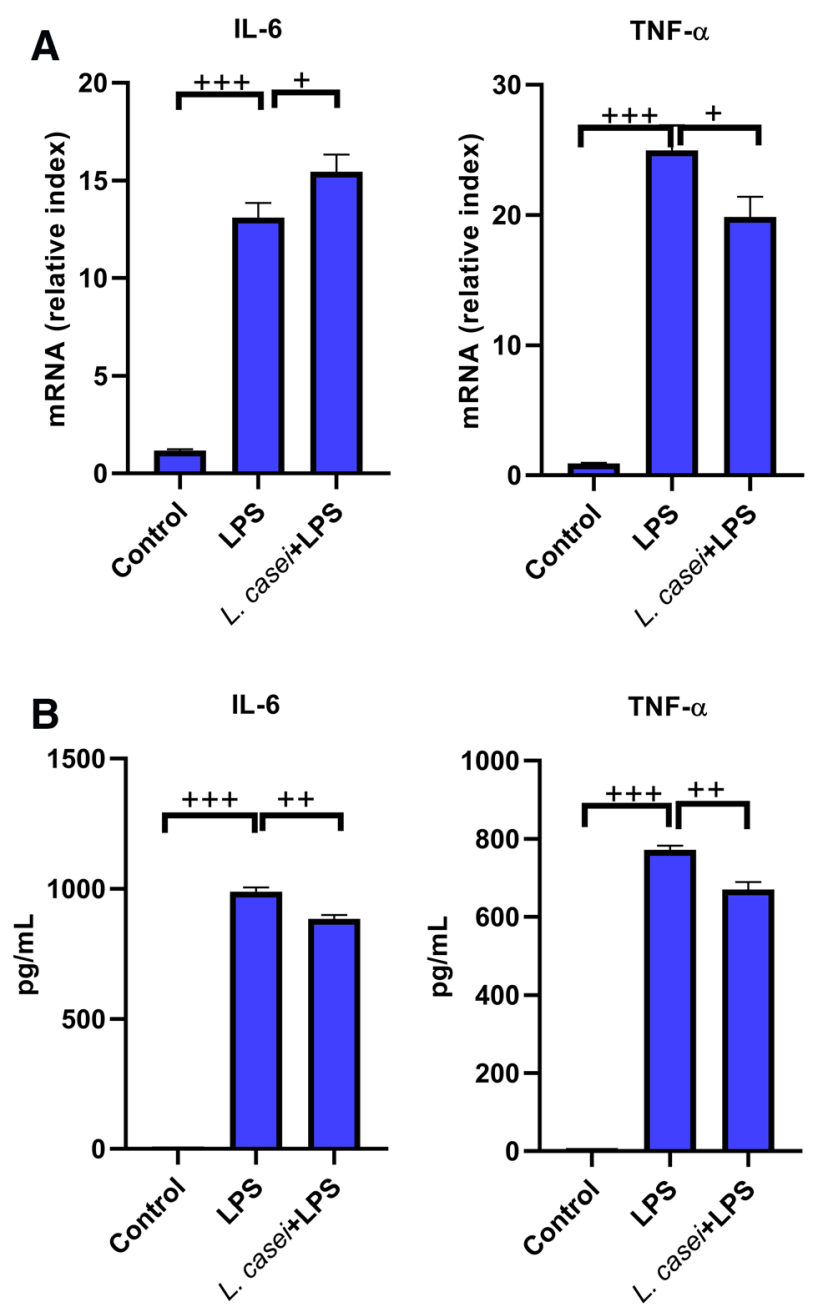

Fig.8 The effects of mouse serum after intragastric administration of Lactobacillus on the mRNA and protein expression of IL-6 and TNF$\alpha$ in human lung cell line (HLF-A). The transcription level was detected by qPCR (a). The protein level was detected by ELISA (b). Control is a blank group only incubated with equal volume of normal saline. LPS is stimulated with $80 \mathrm{ng} / \mathrm{mL}$ LPS. L.casei + LPS is preincubated with $2 \%$ mouse serum for $2 \mathrm{~h}$, and then stimulated with $80 \mathrm{ng} / \mathrm{mL}$ LPS. The values were expressed as mean $\pm \mathrm{SD}$, and experiments were repeated 3 times. $+P<0.05,++P<$ $0.01,+++P<0.001$

infection [10]. The inflammatory response of lung tissue after ALI can be seen as a series of stress responses of lung tissue to injury, including increased capillary permeability of lung tissue, liquid and plasma protein leakage and a large number of white blood cells migrated to the inflammatory area [16]. Pulmonary edema is a typically clinical pathological sign after ALI. The wet/dry weight ratio of lung tissue is an index of systemic and focal inflammatory response and an evaluation parameter of pulmonary edema. Neutrophils are the marker cells of ALI inflammatory response, which can express a variety of cytotoxic products and are the final responsive cells that cause pulmonary capillary and alveolar damage [17]. After ALI, neutrophils 
are activated, then rapidly accumulate, adhere and migrate, stimulating the final release of inflammatory mediators and oxygen free radicals, ultimately aggravating the process of lung injury [18]. The L. casei LC2W screened in this study could significantly reduce the wet/dry weight ratio of lung tissue in mice with ALI, and decrease the number of white cells in BALF, presenting a good protective effect on ALI.

LPS used for modeling is a component of the outer part of the cell wall of gram-negative bacteria, which can induce the body to produce a large number of inflammatory mediators, such as interleukin-6 (IL-6) and tumor necrosis factor TNF- $\alpha$, leading to severe pneumonia. It is widely used to make ALI models [19, 20]. Toll-like receptors (TLRs) are one of the cell transmembrane receptors and pathogen pattern recognition receptors in the innate immune system. Studies have shown that TLRs play a bridge role in initiating the early inflammatory response and connecting the acquired immunity in ALI, thus participating the occurrence and development of ALI [21]. TLR4 is the most important receptor that mediates LPS response [22]. Researchers generally believe that TLR4 is an indispensable transmembrane transduction receptor that transduces LPS signals from extracellular to intracellular [23]. Other than activating innate immunity, TLR4 also induces ALI through inflammatory signaling pathways such as nuclear factor $\kappa \mathrm{B}(\mathrm{NF}-\kappa \mathrm{B})$. After TLR4 activation, NF- $\kappa B$ can be phosphorylated through myeloid differentiation factor 88 (MyD88)-dependent signaling pathway, inducing and aggravating inflammatory response [24]. MyD88 is an important junction protein for TLR4 to transmit signals, and is one of the downstream signal proteins of TLR4 signaling pathway. The death domain of MyD88 binds to the death domain of interleukin receptorrelated kinase (IRAK), resulting in the phosphorylation of IRAK itself, resulting in the activation of NF- $\kappa B$ [25]. The activation of NF- $\kappa \mathrm{B}$ is involved in many processes such as inflammatory response, oxidative stress and apoptosis [26]. After activation of NF- $\kappa B$, NF- $\kappa \mathrm{B}-\mathrm{p} 65$ was transferred from cytoplasm to nucleus, resulting in increased transcription of NF- $\mathrm{BB}-\mathrm{p} 65$, then expressions of pro-inflammatory cytokines such as IL-6 and TNF- $\alpha$ were upregulated, initiating releases of inflammatory factors, which directly led to lung injury [27]. We can see that TLR4/MyD88/NF- $\kappa B$ signaling pathway plays an important role in the progression of ALI. Patients with severe ALI will have progressive hypoxemia, and hypercapnia may occur after mechanical ventilation. Moreover, the coexistence of hypoxemia and hypercapnia will lead to the destruction of blood-brain barrier, which may be related to IRAK-1 and p-IRAK-1-mediated signaling pathways [28]. Therefore, how to effectively alleviate the inflammatory cascade induced by TLR4/MyD88/NF- $\kappa B$ signaling pathway is the focus of treatment [29].
Lactobacillus is a probiotics with reliable safety and good absorption that can be applied to infants and young children. Previous animal experiments and clinical studies have shown that Lactobacillus has certain effects in preventing and controlling pneumonia [6-9, 30]. However, it has not been reported to explore the molecular mechanism of Lactobacillus by inhibiting TLR4-induced MyD88-dependent pathway and reducing IRAK phosphorylation, thereby inhibiting NF- $\kappa B$ signaling pathway and ultimately reducing inflammation. In this study, we intragastrically administered $L$. casei $\mathrm{LC} 2 \mathrm{~W}$, and found that TLR4 and MyD88 in ALI mice had no significant difference (data were not listed), but the phosphorylation of IRAK began to change. The expressions of p-IRAK-1, NF- $\kappa B-p 65$ and p-NF- $\kappa B-p 65$ were significantly inhibited, and the expressions of IL- 6 , TNF- $\alpha$ and ICAM- 1 in lung tissue and serum were significantly decreased. IL-10 is a cytokine necessary to eliminate bacteria and prevent lung tissue damage [31]. After intragastric administration of $L$. casei $\mathrm{LC} 2 \mathrm{~W}$, the expression of IL-10 protein in lung tissue and serum of ALI mice was significantly increased, and the enhancement effect was stronger than that of dexamethasone positive control group, indicating that $L$. case $i \mathrm{LC} 2 \mathrm{~W}$ pretreatment effectively alleviated systemic and local immune responses induced by ALI.

After intraperitoneal injection of LPS, macrophages and other immune cells were activated to produce pro-inflammatory cytokines such as IL-6, TNF- $\alpha$ and promote the development of ALI. IL- 6 is a cytokine with a variety of immune regulatory functions, which can stimulate the proliferation of B cells, T cells and stem cells, promote the production of immunoglobulin through $\mathrm{B}$ cells, and is conducive to the differentiation of cytotoxic lymphocytes and stem cells [32]. TNF- $\alpha$ plays an important role in cell injury and dysfunction, and the level of TNF- $\alpha$ is positively related with the degree of cell injury [33]. Probiotics can effectively strengthen innate and acquired immune system, playing a role in protecting the body. The immune system is essential in the process of anti-inflammatory action. We used the serum of $L$. casei $\mathrm{LC} 2 \mathrm{~W}$ mice to pre-incubate RAW264.7 macrophages, and then stimulated them with LPS. It was found that the levels of IL- 6 and TNF- $\alpha$ that were highly expressed in RAW264.7 macrophages induced by LPS were significantly down-regulated. We speculated that after $L$. casei $\mathrm{LC} 2 \mathrm{~W}$ was intragastrically administered, it might interact with intestinal epithelial cells to produce related substances, and act on the lungs through circulation, which might involve the intestinal-pulmonary axis, and ultimately improve the immune function of mice. The related substances in the serum of mice could inhibit LPSinduced inflammatory response. Studies have shown that $L$. reuteri FLRE5K1 can stimulate the internal system to produce anti-cancer cytokines after intragastric 
administration to mice, on top of that, mouse serum inhibited melanoma cells B16-F10 [34], which is similar to our results. In addition, the mouse serum after intragastric administration of Lactobacillus also had an effect on human lung cell lines, suggesting that Lactobacillus might prevent human ALI, possessing a good clinical transformation vision.

In summary, our study showed that L. casei LC2W pretreatment via intragastric administration might take effects through circulation to reach the lungs, down-regulating the expression of TLR4/MyD88/NF- $\kappa \mathrm{B}$ signaling pathway to inhibit LPS-induced ALI inflammatory response and alleviate lung injury as a result. The component analysis of serum from mice fed with Lactobacillus remains to be further explored in the future.

Acknowledgements We would like to thank the Qiqihar Municipal Bureau of Science and Technology for the financial support.

Authors' contribution Lihui Zhao conceived this study and drafted this manuscript. The strain screening was conducted by Ying Mao. Ying Mao, Haiming $\mathrm{Yu}$, and $\mathrm{He}$ Liu conducted the ALI model construction. The in-vivo sample related biological assays were conducted by Chao Wang, Jianwei Liu, Yutong Han, and Yang Bi who were unaware of the grouping. The cell culture and related models were conducted by Ying Mao and Haiming Yu. Chao Wang and Jianwei Liu unaware of grouping completed the in-vitro ELISA and qPCR assays. Statistical analysis and chart drawings were performed by Donghai Zhang who was blinding to grouping.

Funding Our work was funded by the joint guidance project plan of the Qiqihar Municipal Bureau of Science and Technology (grant number: LHYD-202046).

Availability of data and materials Not applicable on line, but data are prepared upon request.

Code availability Not applicable.

\section{Declarations}

Conflict of interest We declare that no potential conflicts of interest exist.

Ethics approval The Animal Ethical Care Committee of Qiqihar Medical University has approved our protocol (ethical clearance number: QMU-AECC-2020-64).

\section{References}

1. Mowery NT, Terzian W, Nelson AC (2020) Acute lung injury. Curr Probl Surg 57:100777. https://doi.org/10.1016/j.cpsurg. 2020.100777

2. Tolle LB, Standiford TJ (2013) Danger-associated molecular patterns (DAMPs) in acute lung injury. J Pathol 229:145-156. https://doi.org/10.1002/path.4124

3. Devine DA, Marsh PD, Meade J (2015) Modulation of host responses by oral commensal bacteria. J Oral Microbiol 7:26941. https://doi.org/10.3402/jom.v7.26941
4. Mendes V, Galvão I, Vieira AT (2019) Mechanisms by which the gut microbiota influences cytokine production and modulates host inflammatory responses. J Interferon Cytokine Res 39:393-409. https://doi.org/10.1089/jir.2019.0011

5. Galvão I, Tavares LP, Corrêa RO, Fachi JL, Rocha VM, Rungue M, Garcia CC, Cassali G, Ferreira CM, Martins FS, Oliveira SC, Mackay CR, Teixeira MM, Vinolo M, Vieira AT (2018) The metabolic sensor GPR43 receptor plays a role in the control of klebsiella pneumoniae infection in the lung. Front Immunol 9:142. https://doi.org/10.3389/fimmu.2018.00142

6. Griet M, Zelaya H, Mateos MV, Salva S, Juarez GE, de Valdez GF, Villena J, Salvador GA, Rodriguez AV (2014) Soluble factors from Lactobacillus reuteri CRL1098 have anti-inflammatory effects in acute lung injury induced by lipopolysaccharide in mice. PLoS ONE 9:e110027. https://doi.org/10.1371/journal. pone. 0110027

7. Spacova I, Van Beeck W, Seys S, Devos F, Vanoirbeek J, Vanderleyden J, Ceuppens J, Petrova M, Lebeer S (2020) Lactobacillus rhamnosus probiotic prevents airway function deterioration and promotes gut microbiome resilience in a murine asthma model. Gut Microbes 11:1729-1744. https://doi.org/10. 1080/19490976.2020.1766345

8. Vareille-Delarbre M, Miquel S, Garcin S, Bertran T, Balestrino D, Evrard B, Forestier C (2019) Immunomodulatory effects of lactobacillus plantarum on inflammatory response induced by Klebsiella pneumoniae. Infect Immun. https://doi.org/10.1128/ IAI.00570-19

9. Guo C, Lei M, Wang Y, Hua L, Xue S, Yu D, Zhang C, Wang D (2018) Oral administration of probiotic lactobacillus casei shirota decreases pneumonia and increases pulmonary functions after single rib fracture: a randomized double-blind, placebo-controlled clinical trial. J FOOD SCI 83:2222-2226. https://doi.org/ 10.1111/1750-3841.14220

10. Liu TY, Zhao LL, Chen SB, Hou BC, Huang J, Hong X, Qing L, Fang Y, Tao Z (2020) Polygonatum sibiricum polysaccharides prevent LPS-induced acute lung injury by inhibiting inflammation via the TLR4/Myd88/NF- $\kappa B$ pathway. Exp Ther Med 20:3733-3739. https://doi.org/10.3892/etm.2020.9097

11. Ju M, Liu B, He H, Gu Z, Liu Y, Su Y, Zhu D, Cang J, Luo Z (2018) MicroRNA-27a alleviates LPS-induced acute lung injury in mice via inhibiting inflammation and apoptosis through modulating TLR4/MyD88/NF- $\kappa$ B pathway. Cell Cycle 17:2001-2018. https://doi.org/10.1080/15384101.2018.1509635

12. Suzuki T, Tada Y, Gladson S, Nishimura R, Shimomura I, Karasawa S, Tatsumi K, West J (2017) Vildagliptin ameliorates pulmonary fibrosis in lipopolysaccharide-induced lung injury by inhibiting endothelial-to-mesenchymal transition. Respir Res 18:177. https://doi.org/10.1186/s12931-017-0660-4

13. Liang Y, Yang N, Pan G, Jin B, Wang S, Ji W (2018) Elevated IL-33 promotes expression of MMP2 and MMP9 via activating STAT3 in alveolar macrophages during LPS-induced acute lung injury. Cell Mol Biol Lett 23:52. https://doi.org/10.1186/s11658018-0117-x

14. Zhang J, Xiao F, Zhang L, Wang X, Lai X, Shen Y, Zhang M, Zhou B, Lang H, Yu P, Hua F (2018) Alpha-lipoic acid preconditioning and ischaemic postconditioning synergistically protect rats from cerebral injury induced by ischemia and reperfusion partly via inhibition TLR4/MyD88/ NF- $\kappa \mathrm{B}$ signaling pathway. Cell Physiol Biochem 51:1448-1460. https://doi.org/10. $1159 / 000495593$

15. Song C, Yang X, Lei Y, Zhang Z, Smith W, Yan J, Kong L (2019) Evaluation of efficacy on RANKL induced osteoclast from RAW264.7 cells. J Cell Physiol 234:11969-11975. https:// doi.org/10.1002/jcp. 27852

16. Cuzzocrea S (2005) Shock, inflammation and PARP. Pharmacol Res 52:72-82. https://doi.org/10.1016/j.phrs.2005.02.016 
17. Pinheiro A, Mendes A, Neves M, Prado CM, Bittencourt-Mernak MI, Santana F, Lago J, de Sá JC, Da RC, de Sousa EM, Fontes VC, Grisoto M, Falcai A, Lima-Neto LG (2019) Galloyl-hexahydroxydiphenoyl (HHDP)-glucose isolated from Punica granatum L. leaves protects against lipopolysaccharide (LPS)induced acute lung injury in BALB/c mice. Front Immunol 10:1978

18. Caudrillier A, Kessenbrock K, Gilliss BM, Nguyen JX, Marques MB, Monestier M, Toy P, Werb Z, Looney MR (2012) Platelets induce neutrophil extracellular traps in transfusion-related acute lung injury. J Clin Invest 122:2661-2671. https://doi.org/10.1172/ JCI61303

19. Cao F, Tian X, Li Z, Lv Y, Han J, Zhuang R, Cheng B, Gong Y, Ying B, Jin S, Gao Y (2020) Suppression of NLRP3 inflammasome by erythropoietin via the EPOR/JAK2/STAT3 pathway contributes to attenuation of acute lung injury in mice. Front Pharmacol 11:306. https://doi.org/10.3389/fphar.2020.00306

20. D'Alessio FR (2018) Mouse models of acute lung injury and ARDS. Methods Mol Biol 1809:341-350. https://doi.org/10. 1007/978-1-4939-8570-8_22

21. Zhang T, Wang J, Wang S, Ma C (2015) Timosaponin B-II inhibits lipopolysaccharide-induced acute lung toxicity via TLR/ NF- $\kappa$ B pathway. Toxicol Mech Methods 25:665-671. https://doi. org/10.3109/15376516.2015.1045652

22. Li Z, Xiao X, Yang M (2016) Asiatic acid inhibits lipopolysaccharide-induced acute lung injury in mice. Inflammation 39:1642-1648. https://doi.org/10.1007/s10753-016-0398-z

23. Rocha DM, Caldas AP, Oliveira LL, Bressan J, Hermsdorff HH (2016) Saturated fatty acids trigger TLR4-mediated inflammatory response. Atherosclerosis 244:211-215. https://doi.org/10.1016/j. atherosclerosis.2015.11.015

24. Zeng H, Yang L, Zhang X, Chen Y, Cai J (2018) Dioscin prevents LPS-induced acute lung injury through inhibiting the TLR4/MyD88 signaling pathway via upregulation of HSP70. Mol Med Rep 17:6752-6758. https://doi.org/10.3892/mmr.2018.8667

25. Jiang Q, Wang S, Shi Y (2019) Posttreatment with LYRM03 protects rats from acute lung inflammation induced by lipopolysaccharide via suppressing the NF- $\kappa \mathrm{B} / \mathrm{MyD} 88 / \mathrm{TLR} 4$ axis. J SURG RES 243:316-324. https://doi.org/10.1016/j.jss. 2019.05.036

26. Jin W, Zhang Y, Xue Y, Han X, Zhang X, Ma Z, Sun S, Chu X, Cheng J, Guan S, Li Z, Chu L (2020) Crocin attenuates isoprenaline-induced myocardial fibrosis by targeting TLR4/NF- $\mathrm{KB}$ signaling: connecting oxidative stress, inflammation, and apoptosis. Naunyn Schmiedebergs Arch Pharmacol 393:13-23. https:// doi.org/10.1007/s00210-019-01704-4
27. Qin L, Tan HL, Wang YG, Xu CY, Feng J, Li M, Dou YQ (2018) Astragalus membranaceus and Salvia miltiorrhiza ameliorate lipopolysaccharide-induced acute lung injury in rats by regulating the toll-like receptor 4/nuclear factor-kappa B signaling pathway. Evid Based Complement Alternat Med 2018:3017571. https:// doi.org/10.1155/2018/3017571

28. Ding H, Liu X, Li X, Wen M, Li Y, Han Y, Huang L, Liu M, Zeng H (2020) Hypercapnia exacerbates the disruption of the blood-brain barrier by inducing interleukin- $1 \beta$ overproduction in the blood of hypoxemic adult rats. Int J Mol Med 46:762-772. https://doi.org/10.3892/ijmm.2020.4604

29. Akhter N, Hasan A, Shenouda S, Wilson A, Kochumon S, Ali S, Tuomilehto J, Sindhu S, Ahmad R (2018) TLR4/MyD88-mediated CCL2 production by lipopolysaccharide (endotoxin): implications for metabolic inflammation. J Diabetes Metab Disord 17:77-84. https://doi.org/10.1007/s40200-018-0341-y

30. Karacaer F, Hamed I, Özogul F, Glew RH, Özcengiz D (2017) The function of probiotics on the treatment of ventilator-associated pneumonia (VAP): facts and gaps. J Med Microbiol 66:1275-1285. https://doi.org/10.1099/jmm.0.000579

31. Peñaloza HF, Noguera LP, Ahn D, Vallejos OP, Castellanos RM, Vazquez Y, Salazar-Echegarai FJ, González L, Suazo I, PardoRoa C, Salazar GA, Prince A, Bueno SM (2019) Interleukin-10 produced by myeloid-derived suppressor cells provides protection to carbapenem-resistant klebsiella pneumoniae sequence type 258 by enhancing its clearance in the airways. Infect Immun. https://doi.org/10.1128/IAI.00665-18

32. Zhou L, Liu Z, Wang Z, Yu S, Long T, Zhou X, Bao Y (2017) Astragalus polysaccharides exerts immunomodulatory effects via TLR4-mediated MyD88-dependent signaling pathway in vitro and in vivo. Sci Rep 7:44822. https://doi.org/10.1038/srep44822

33. Xu C, Chen G, Yang W, Xu Y, Xu Y, Huang X, Liu J, Feng Y, Xu Y, Liu B (2015) Hyaluronan ameliorates LPS-induced acute lung injury in mice via Toll-like receptor (TLR) 4-dependent signaling pathways. Int Immunopharmacol 28:1050-1058. https://doi.org/10.1016/j.intimp.2015.08.021

34. Luo M, Hu M, Feng X, XiaoLi W, Dong D, Wang W (2020) Preventive effect of Lactobacillus reuteri on melanoma. Biomed Pharmacother 126:109929. https://doi.org/10.1016/j.biopha.2020. 109929

Publisher's Note Springer Nature remains neutral with regard to jurisdictional claims in published maps and institutional affiliations. 